\title{
TALAK TAKLIK MENURUT FIQAH: ANALISIS PELAKSANAANNYA DALAM UNDANG-UNDANG KELUARGA ISLAM SERTA ARAHAN AMALAN JABATAN KEHAKIMAN SYARIAH MALAYSIA
}

(Conditional Divorce in Islamic Jurisprudence: An Analysis of its Application in Islamic Family Law and the Practice Direction of the Department of Syariah Judiciary Malaysia)

\author{
Miszairi Sitiris* \\ miszairi@iium.edu.my \\ Mustafa Mat Jubri@ Shamsuddin \\ mussham@iium.edu.my
}

Mohamad Sabri bin Zakaria

sabriz@iium.edu.my

Jabatan Fiqh dan Usul Al-Fiqh, Kulliyyah Ilmu Wahyu dan Sains Kemanusiaan, Universiti Islam Antarabangsa Malaysia.

Mohd Na'im Mokhtar

naim1@esyariah.gov.my

Jabatan Kehakiman Syariah Malaysia

Terbit dalam talian (published online): 7 Januari 2021

Sila rujuk: Miszairi Sitiris, Mustafa Mat Jubri@ Shamsuddin, dan Mohd Na'im Mokhtar. (2021). Talak Taklik Menurut Fiqah: Analisis Pelaksanaannya dalam Undang-Undang Keluarga Islam serta Arahan Amalan Jabatan Kehakiman Syariah Malaysia. Kanun: Jurnal Undangundang Malaysia, 33(1), 97-130.

\footnotetext{
Abstrak

Artikel ini mengkaji hikmah di sebalik pensyariatan talak taklik, hukum serta syarat yang ditetapkan menurut pandangan ulama, di samping 
bentuk atau jenis taklik yang ada dalam syariah Islam. Artikel ini juga cuba melihat pengamalan taklik di Malaysia serta peruntukan yang ada dalam Undang-Undang Keluarga Islam serta arahan amalan yang dikeluarkan oleh Jabatan Kehakiman Syariah Malaysia berkaitan dengan syarat-syarat yang ditetapkan bagi mensabitkan penceraian secara taklik. Kajian ini mengaplikasikan kaedah penyelidikan perpustakaan terhadap penulisan ulama terdahulu daripada pelbagai mazhab fikah yang muktabar serta kajian teks terhadap peruntukan undang-undang berkaitan dengan tajuk yang dibincangkan. Hasil kajian mendapati bahawa lafaz taklik rasmi bagi setiap negeri adalah berbeza, yang menjadikan kesan terhadapnya juga berbeza. Penulis mendapati terdapat kewajaran untuk menilai semula amalan pembacaan lafaz taklik rasmi selepas akad nikah. Di samping itu, pensabitan perceraian secara lafaz taklik adalah lebih rumit jika dibandingkan dengan talak biasa.

Kata kunci: Talak taklik, Undang-Undang Keluarga Islam, Malaysia, lafaz taklik

\begin{abstract}
This article studies the hidden wisdom behind the pronouncement of conditional divorce, the rules and conditions prescribed by the jurists, as well as the forms and types of ta'liq in shariah law. This article also seeks to look at the practice of ta'līq in Malaysia as well as provisions under Islamic family law in Malaysia, as well as the practice direction issued by the Department of Syariah Judiciary Malaysia. The study employed library research to expound the opinions of earlier jurists from various schools of Islamic jurisprudence, and textual studies on the provisions of law related to the issue concerned. The study found that the wording of the official pronouncements of ta'liq varies from state to state, hence the consequences can also differ. The researcher is of the view that the practice of pronouncing ta'liq after the solemnization of a marriage contract should be reviewed. It needs to be said that the validation of a divorce by ta'liq is a more complicated process than an ordinary divorce.
\end{abstract}

Keywords: Conditional divorce, Islamic Family Law, Malaysia,word of stipulation 


\section{PENGENALAN}

Syariah Islam menerima talak taklik sebagai salah satu kaedah pembubaran perkahwinan atau penceraian. Dalam keadaan tertentu suami tidak mahu menceraikan isterinya dengan serta-merta atau talak munjiz. Sebaliknya, suami hanya mahu menceraikan isterinya apabila berlaku sesuatu yang tidak diingininya seperti melarang isteri keluar dari rumah, dengan mengatakan kepadanya: "Seandainya kau keluar rumah, maka tertalak engkau". Apabila isteri itu keluar rumah, secara serta-merta talak berlaku. Talak ini dinamakan talak taklik. Terdapat beberapa hikmah yang mungkin dapat difahami di sebalik pensyariatan talak taklik, bentuk serta hukum berkaitan dengan pengamalan talak taklik menurut pandangan ulama. Dalam Undang-Keluarga Islam di Malaysia serta Arahan Amalan Jabatan Kehakiman Syariah Malaysia terdapat peruntukan khas berkaitan dengan talak taklik yang menjadi topik utama perbahasan kajian ini.

\section{PENGERTIAN TALAK TAKLIK}

Taklik, perkataan bahasa Arab berasal dari kata dasar (عَلَقَ - يُعَلِّقُ) yang dari segi bahasa bermaksud: gantung atau sangkut ${ }^{1}$. Dari segi istilah, ta' līq bermaksud: menggantung atau mengaitkan sesuatu dengan sesuatu yang

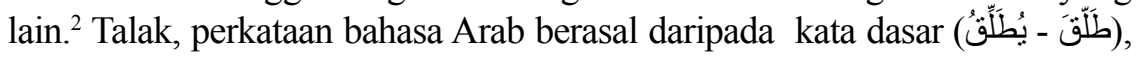
yang dari segi bahasa bermaksud: meleraikan atau melepaskan suatu ikatan. ${ }^{3}$ Dari segi istilah, talak bermaksud:

Meleraikan ikatan perkahwinan dengan serta-merta atau pada masa hadapan dengan syarat-syarat tertentu". ${ }^{4}$ Ahmad al-Dardir mendefinisikan talaq sebagai: "Memutuskan ikatan perkahwinan dengan lafaz yang sarih, atau lafaz kinayah yang zahir, atau apa-apa lafaz dengan niat. ${ }^{5}$

1 Muhammad ibn Abu Bakr. (1986). Mukhtār al-Șihāḥ,189. Muhammad ibn Ya'qub al-Fayruzabadi. (2008). Al-Qāmūs al-Muhìt, 1134.

2 Wizarah al-Awqaf. (1988). Al-Mawsū'ah Al-Fiqhiyyah, v12, 298.

3 Muhammad ibn Abu Bakr. (1986). Mukhtār al-Șihāḥ, 166

4 Wizarah al-Awqaf. (1988). Al-Mawsū'ah al-Fiqhiyyah, v29, 5. Lihat juga, Ibn Nujaym (t.t.). Al-Bahr al-Rā'iq, v3, 252. 'Ala' al-Din al-Kasani. (1986). Badā'i'al-Șanā'i', v3, 11, Ibn Qudamah. (1968). Al-Mughnī, v7, 363. Muhammad al-Ramli. (1984) Nihāyah al-Muhtāj, v6, 423.

5 Ahmad al-Dardir. (t.t.). Al-Sharh al-Kabīr, v2, 347. Lihat, Sa'di Abu Jayb. (2002). Al-Qāmūs al-Fiqhī, 230, telah tersalah rujukan mengatakan ia dari Muhammad al-Dusuki. 
Talak taklik dari segi istilah bermaksud: mengaitkan jatuhnya talak dengan sesuatu perkara, sama ada perbuatan suami sendiri, isteri, orang lain, keadaan, masa depan dan sebagainya. ${ }^{6}$ Contohnya, suami mengatakan kepada isterinya: "Jika engkau keluar rumah, maka tertalak engkau".? Apabila isteri keluar rumah, maka tertalaklah $\mathrm{dia}^{8}$. Istilah ini juga disebut sebagai talak $m u^{\prime}$ allaq ${ }^{9}$ dan talak muqayyad..$^{10}$

\section{HUKUM TALAK TAKLIK DALAM ISLAM}

Terdapat dua pendapat ulama terhadap hukum talak taklik. Pendapat pertama, jumhur ulama dalam kalangan mazhab Hanaf, ${ }^{11}$ mazhab Maliki ${ }^{12}$, mazhab Syafii ${ }^{13}$ dan mazhab Hanbali ${ }^{14}$ sepakat mengatakan bahawa penceraian secara talak taklik adalah sah.

Mereka berhujah dengan firman Allah SWT dalam Surah alBaqarah, ayat 22, yang bermaksud:

"Talak (yang boleh dirujuk kembali itu hanya) dua kali. Sesudah itu bolehlah ia (rujuk dan) memegang terus (isterinya itu) dengan cara yang sepatutnya atau melepaskan (menceraikannya) dengan cara yang baik".

Ayat di atas adalah umum yang menyatakan hak suami menceraikan isteri meliputi penceraian secara talak munjiz (serta-merta), mahupun talak taklik (bersyarat atau berkait). Mereka juga berhujah dengan

6 Wizarah al-Awqaf. (1988). Al-Mawsū'ah al-Fiqhiyyah. v12,314. Lihat, Ahmad al-Dardir. (t.t.). Al-Sharh al-Kabīr, v2, 389. Mutafa al-Khin et al. (1992). Al-Fiqh al-Manhajī. Damshiq: Dar al-Qalam, v4. 134.

7 Ibn Qudamah. (1968). Al-Mughnī, v7, 451.

8 Ibn Qudamah. (1968). Al-Mughnī, v7, 434. Ahmad al-Dardir. (t.t.). Al-Sharḥal-Kabīr, v2, 404.

9 Ali Mahmud al-Zaqili. (2009). Al-Ṭalāq al-Mu'allaq: Mafhūmuhu wa Āthāruhufĩ alFiqh al-Islāmī. Al-'Urdun: al-Majallah al-'Urdumiyyahfi al-Dirawat al-Islamiyyah, 5(1). Lihat juga, Sajidah Taha Mahmud. (2014). At-Ṭalāq al-Mu'allaq: Māhiyyatuhu wa takyīfuhu al-Fiqhī wa al-Qānūn̄. Majalah Kuliyyah al-Tarbiyyah Li al-Banat, 25(2).

10 Ibn Rushd. (2004). Bidāyah al-Mujtahid. Al-Qahirah: Dar al-Hadith, v3, 99.

11 'Ala' al-Din al-Kasani. (1986). Badā'i' al-Sanā'i', v3, 30.

12 Ibn Rushd. (2004). Bidāyah al-Mujtahid, v3, 99.

13 Muhammad al-Sharbini. (1994). Mughnīal-Muhtāj. Dar al-Kutub al-Ilmiyyah, v4, 464.

14 Ibn Qudamah. (1968). Al-Mughnī, v7, 341. 
firman Allah dalam Surah al-Maidah, ayat 1: "Wahai orang-orang yang beriman, penuhi serta sempurnakanlah perjanjian-perjanjian". Talak taklik merupakan suatu perjanjian yang wajib dipenuhi.

Mereka juga bersandarkan kepada sabda Rasulullah SAW:

"Orang Islam terikat dengan syarat-syarat yang mereka tetapkan, kecuali syarat yang mengharamkan yang halal atau menghalalkan yang haram". ${ }^{15}$

Orang Islam wajib memenuhi segala syarat yang ditetapkan, begitu juga syarat dalam talak taklik. Apabila syarat yang terdapat dalam lafaz talak taklik dipenuhi, maka berlakulah talak seperti yang dijanjikan.

Pendapat kedua, Mazhab Zohiri berpendapat bahawa penceraian secara talak taklik adalah tidak sah. ${ }^{16}$ Mereka mengatakan bahawa talak hanya boleh berlaku atau sah dengan munjiz (serta-merta) tanpa taklik (bersyarat atau berkait). Pandangan ini bersandarkan firman Allah SWT dalam Surah al-Talaq, ayat 1, mafhumnya:

"Wahai Nabi! Apabila kamu - (engkau dan umatmu) - hendak menceraikan isteri-isteri (kamu), maka ceraikanlah mereka pada idahnya".

Apakah yang dimaksudkan dengan ayat "Ceraikanlah mereka pada idahnya"? Adalah menceraikan mereka pada masa yang disyariatkan, iaitu ketika isteri suci (tidak dalam keadaan haid) yang tidak disetubuhi? Maksudnya, talak hanya boleh berlaku dengan serta-merta dan tidak boleh bersyarat. Mereka juga berhujah dengan qias terhadap akad nikah yang hanya boleh berlaku dengan serta-merta dan tidak boleh dikaitkan dengan sesuatu atau bersyarat. Begitu juga talak tidak boleh berlaku dengan bersyarat atau dengan taklik.

Pendapat yang rajih berdasarkan hujah yang diberikan oleh pendapat pertama, penulis menganggap bahawa pendapat mereka adalah lebih rajih, kerana tiada dalil yang melarang suami daripada berbuat demikian. Talak taklik merupakan suatu perjanjian yang wajib bagi suami menepatinya. Dalil pendapat kedua yang mengqiaskan talak taklik dengan akad nikah merupakan qiyasma'a al-fariq, iaitu menyamakan dua perkara yang

15 Abu Daud. (t.t.). Sunan Abū Dāwūd. Beirut: Al-Makrabah al-'Asriyyah, v3, 304 (No. 3594).

16 Ibn Hazm. (t.t.). Al-Muḥallā bi al-Āthār. Beirut: Dar Al-Fikr, v9, 126. 
berbeza. Nikah merupakan akad (perjanjian ikatan), manakala talak pula melepaskan atau meleraikan hak (memutuskan ikatan). Maka kedua-duanya tidak boleh disamakan dari sudut pembentukan atau penguatkuasaannya.

\section{Talak Taklik Hak Suami}

Talak taklik merupakan hak mutlak suami. Dalam talak biasa, isteri tiada kuasa untuk menceraikan dirinya sendiri. Begitu juga dengan talak taklik, isteri tiada kuasa melafazkan talak taklik. ${ }^{17}$ Walau bagaimanapun, isteri boleh meminta suami melafazkan talak taklik berdasarkan syarat-syarat yang kehendakinya.

\section{Hukum Talak Taklik}

Seperti talak biasa, hukum asal talak taklik ialah makruh ${ }^{18}$ jika dilakukan tanpa sebab berdasarkan sabda Rasulullah SAW: "Perkara halal yang paling dibenci oleh Allah ta'ala ialah talak". ${ }^{19}$ Asal hukum talak taklik ialah man'u atau larangan. Perbuatan ini tidak dibenarkan melainkan sekiranya terdapat sebab yang dibenarkan oleh syarak, seperti suami ingin melarang isteri keluar dari rumah tanpa memakai pakaian yang menutup aurat dan sebagainya. Hukum talak taklik boleh menjadi haram seandainya tujuan suami adalah untuk mendera isteri secara mental, seperti suami melarang isteri melakukan kewajipan agama, contohnya isteri dilarang membaca al-Quran.

\section{Talak Taklik Tidak Boleh Ditarik Balik}

Jumhur ulama sepakat mengatakan bahawa talak taklik tidak boleh ditarik balik atau dibatalkan. ${ }^{20}$ Timbul persoalan kepada mereka yang telah terlanjur melafazkan talak taklik kepada isterinya dengan talak tiga. Seperti ucapan suami: "Seandainya engkau balik ke rumah emak engkau, tertalak engkau dengan talak tiga". Adakah terdapat cara untuk membatalkan talak taklik tersebut? Imam al-Shayrazi, ulama mazhab Shafie, menyatakan bahawa seandainya suami menceraikan isteri secara

17 Mansur Al-Bahuti. (t.t.). Kasysyāf Al-Qinā', v5, 285.

18 Ahmad al-Dardir. (t.t.). Al-Sharh al-Kabīr, v2, 389.

19 Ibnu Majah. (t.t.). Sunan Ibn Mājah, v1, 650 (No. 2018).

20 Muhammad al-Sharbini. (1994). Mughnī al-Muḥtāj, v4, 442. Muhyi al-Din al-Nawawi. (1991). Rawḍah al-Ṭālibīn, v8, 158. 
ba'in, sama ada dengan menceraikannya dengan talak raj'i, hingga berakhir tempoh idah lalu bertukar menjadi talak $b a^{\prime}$ in, atau dengan cara khulu', kemudian isteri melakukan perkara yang disyaratkan (balik ke rumah emak) sebelum mereka berkahwin semula, maka hilanglah syarat taklik tersebut. ${ }^{21}$

\section{HIKMAH PENSYARIATAN TALAK TAKLIK}

Antara hikmah pensyariatan talak taklik termasuklah:

1. Mendidik isteri: Seperti suami melafazkan talak taklik kepada isterinya yang sering keluar rumah tanpa izin suami walaupun telah diberikan peringatan agar tidak mengulangi perbuatannya itu.

2. Memelihara hak dan kebajikan isteri: Seperti isteri meminta kepada suami melafazkan talak taklik agar tidak memukulnya atau meninggalkannya tanpa nafkah dan sebagainya, agar menjadikan suami lebih bertanggungjawab terhadap isteri.

3. Meyakinkan isteri: Kadang-kadang suami melafazkan talak taklik bagi mendapatkan keyakinan isteri bahawa dia tidak akan mengulangi tabiat buruk yang pernah dilakukan sebelum ini seperti berjudi dan sebagainya.

\section{SYARAT SAH TALAK TAKLIK}

Terdapat beberapa syarat yang perlu dipenuhi untuk talak taklik menjadi sah.

\section{Syarat Suami}

Suami sempurna berkeahlian sebagai mukalaf, iaitu akil baligh. Maka tidak sah lafaz talak taklik yang diucapkan oleh suami yang tidak siuman atau gila ${ }^{22}$. Suami melafazkan talak taklik dengan sukarela tanpa dipaksa. Tidak sah lafaz talak taklik yang diucapkan dengan cara paksaan. ${ }^{23}$

21 Ibrahim Al-Shayrazi. (t.t.). Al-Muhadhdhab, v3, 41, Daud Al-Fathani. (1917). 'Ị̂ạh Al-Bāb limazīd Al-Nikāh bi Al-Ṣawāb, 129-130.

22 Muhyi al-Din al-Nawawi. (t.t.). Al-Majmu'. Dar al-Fikr, v10, 227.

23 Muhyi al-Din al-Nawawi. (t.t.). Al-Majmu', v10, 227. Ibn Qudamah. (1968). Al-Mughnī, v7, 382, 


\section{Syarat Isteri}

Isteri berada dalam status isteri yang sah, termasuk isteri yang berada dalam tempoh idah talak raj $i i^{24}$ Isteri yang berada dalam tempoh idah talak raj ' $i$ masih dianggap sebagai isteri yang sah memandangkan isteri masih berhak mendapat nafkah, sama ada isteri hamil atau tidak, suami boleh kembali kepada isterinya dengan lafaz rujuk tanpa perlu akad baharu dan suami isteri masih mewarisi jika salah seorang meninggal dunia. Talak taklik tidak sah diucapkan kepada perempuan yang bukan isterinya.

\section{Syarat Lafaz Taklik}

Lafaz yang digunakan menunjukkan ada perkaitan antara talak dengan perkara yang ditaklikkan, atau disebut juga dengan adawatal-syart, seperti perkataan: "jika", "kalau", "apabila" dan "seandainya". ${ }^{25}$

Pada pandangan penulis, lafaz taklik yang dilafazkan hendaklah memberikan pengertian insya'i dan bukan khabari. Insya'i bermaksud mencetus atau menerbit. Contoh lafaz: "Kalau kau keluar rumah, tertalaklah engkau" atau "Engkau tertalak jika keluar rumah". Khabari bermaksud memberitahu atau memberi khabar. Contoh lafaz: "Kalau kau keluar rumah, aku akan talak engkau". Lafaz talak taklik yang memberikan maksud perkhabaran tidak menyebabkan jatuh talak. Suami ingin memberitahu bahawa apabila berlaku perkara yang ditaklikkan, suami akan mentalakkannya dan masih belum tertalak lagi. Seandainya suami berkeinginan untuk menceraikannya maka suami perlu melafazkan talak. Seandainya tidak, maka talak tidak berlaku. ${ }^{26}$

Penulis berpandangan bahawa ucapan suami: "Kalau kau keluar rumah, aku talak engkau". Ucapan ini adalah samar-samar antara insya'i dengan khabari. Oleh sebab itu, suami dikehendaki memberikan penjelasan atau kepastian. Ikatan perkahwinan tidak boleh dibina atas dasar keraguan. Seandainya suami mengatakan bahawa dia berniat cerai, maka jatuh talak. Jika suami mengatakan tidak, maka talak tidak jatuh.

24 Muhammad al-Sharbini. (1994). Mughnī al-Muḥtāj, v4, 476.

25 Mansur al-Bahuti. (t.t.). KasysyāfAl-Qinā', v5, 288. Muhyi al-Din al-Nawawi. (1991). Raw ḍah al-Ṭălibīn, v8, 128. Al-Husain al-Baghawi. (1997). Al-Tahdhīb, v6, 54. Ibrahim al-Shayrazi. (t.t.). Al-Muhadhdhab, v3, 21. Muhammad Mahmud. (2016). Ba'ḍu Adawāt al-Sharțwa Āthāruhafī Aḥkām al-Ṭalāq. Dirasat: Ulum al-Shariahwa al-Qanun, Vol. 43, No. 2.

26 Muhammad al-Sharbini. (1994). Mughnī al-Muḥtāj, v4, 533. 
Ulama turut berbeza pendapat seandainya ucapan suami tidak disertakan dengan adawatal-syart. Seperti ucapan suami: "Kau keluar, kau tertalak". Pandangan pertama mengatakan bahawa lafaz taklik tersebut adalah tidak sah, dan isteri tidak tercerai jika keluar rumah kerana tidak memenuhi syarat lafaz taklik. Pendapat kedua, mengatakan bahawa lafaz taklik tersebut adalah sah, dan isteri tertalak jika keluar dari rumah. Pendapat kedua berdasarkan kaedah fiqah: $i$ "malal-kalamawlamin ihmalihi bermaksud "beramal (mengambil kira) dengan kata-kata yang diucapkan lebih baik daripada mengabaikannya". Pendapat ketiga, mengatakan bahawa suami perlu ditanya maksud ucapannya sama ada dia berniat talak taklik atau tidak. Jika suami berniat talak taklik, maka talak jatuh jika isteri keluar. Jika suami tidak berniat talak taklik, maka talak tidak jatuh jika isteri keluar. ${ }^{27}$ Pendapat yang rajih, penulis berpandangan bahawa lafaz tersebut adalah samar dan menyamai lafaz kinayah. Oleh itu, penjelasan perlu diperoleh sama ada suami berniat talak taklik, berdasarkan kepada kaedah: (al-sarih: lahtaji ila niyyah, wa al-kinayah: la talzami illa bi al-niyyah) ${ }^{28}$ bermaksud: "Lafaz sarih tidak memerlukan niat, manakala lafaz kinayah, tidak berlaku melainkan dengan niat". Keadaan ini bersesuaian dengan pandangan pendapat ketiga.

\section{Syarat Perkara yang Ditaklikkan}

Perkara yang ditaklikkan atau dikaitkan ialah perkara yang boleh berlaku. ${ }^{29}$ Walau bagaimanapun, seandainya suami melafazkan talak taklik dengan perkara yang mustahil berlaku atau tidak mungkin akan berlaku, ulama mempunyai pandangan yang berbeza seperti yang akan dijelaskan nanti.

\section{BENTUK/JENIS TALAK TAKLIK}

Bentuk atau jenis talak taklik dapat dibahagikan berdasarkan perkara yang disyaratkan pada talak itu seperti yang berikut:

27 Jalal al-Din al-Suyuthi. (1983). Al-Asybah wa al-Nażā'ir. Beirut: Dar Al-KutubAlIlmiyyah, 129.

28 Jalal al-Din al-Suyuthi. (1983). Al-Asybah wa al-Nazā' 'ir, 293-294.

29 Ahmad al-Dardir. (t.t.). Al-Sharh al-Kabīr. Dar al-Fikr, v2, 389. 


\section{(1) Talak Taklik dengan Syarat}

Talak taklik dengan syarat bermaksud talak yang dikaitkan dengan syarat, iaitu mengaitkan jatuhnya talak dengan syarat-syarat tertentu. Talak taklik dengan syarat boleh berlaku dengan pelbagai cara, sama ada dengan perbuatan suami, isteri, orang lain dan sebagainya. Istilah ini juga disebut dengan al-talaq al-mu'allaq. Imam al-Sarkhasi menjelaskan al-talaq almu'allaq ialah "talak bersyarat yang berlaku apabila terlaksana syarat tersebut seperti talak munjiz (serta-merta)". ${ }^{30}$

Contoh peristiwa:

- Perbuatan suami: Seperti ucapan suami kepada isterinya: "Seandainya aku berkahwin lagi, maka tertalaklah (atau cerailah) engkau".

- Perbuatan isteri: Seperti ucapan suami kepada isterinya: "Seandainya engkau menelefon lelaki itu lagi, maka tertalaklah engkau".

- Perbuatan orang lain: Seperti ucapan suami kepada isterinya: "Seandainya Abu pulang, maka tertalaklah engkau".

- Perbuatan makhluk lain: Antaranya termasuklah binatang, seperti ucapan suami: "Seandainya kucing itu bersalin, maka tertalaklah engkau", atau kejadian alam, seperti ucapan suami: "Seandainya hari hujan, tertalaklah engkau".

Ulama berbeza pandangan sama ada talak taklik dengan syarat ini sah atau tidak kepada tiga pendapat:

\section{(i) Pendapat pertama: Talak taklik dengan syarat adalah sah}

Pendapat ini dipegang oleh mazhab ulama yang empat daripada mazhab Hanafi, ${ }^{31}$ mazhab Maliki, ${ }^{32}$ mazhab Syafii ${ }^{33}$ dan mazhab Hanbali. ${ }^{34}$

30 Muhammad ibn Ahmad al-Sarkhasi. (1993). Al-Mabsūtt. Beirut: Dar al-Makrifah, v8, 136. Lihat juga, Abu al-Hasan al-Maturidi. (1999). Al-Ṣāwī al-Kabīr. Beirut: Dar alKutub al-'Ilmiyyah, v10, 193.

31 'Ala' al-Din al-Kasani. (1986). Badā'i' al-Ṣanā'i', v3, 126. Ali al-Marghinani. (t.t.). Al-Hidāyah. Beirut: Dar Ihya' al-Turath Al-'Arabi, v1, 244.

32 Ibn Rusd. (2004). Bidāyah al-Mujtahid. Al-Qahirah: Dar al-Hadith, v3, 103.

33 Muhammad al-Sharbini. (1994). MughnīAl-Muḥtāj, v4, 505. Muhyi al-Din al-Nawawi. (1991). Raw ḍahAl-Ṭālibīn, v8, 176.

34 IbnQudamah. (1968). Al-Mughnī, v7, 427. Ibn Qudamah. (1994). Al-Kāfī, v3, 126. 
Mereka berhujah, seperti yang telah dijelaskan di atas, bahawa talak taklik merupakan suatu perjanjian. Sebagai perjanjian adalah wajib untuk dipenuhi berdasarkan banyak dalil sama ada daripada al-Quran mahupun sunah.

Jika talak taklik dengan syarat dikaitkan dengan perbuatan orang lain atau isteri, lihat kepada niat suami. Sekiranya suami berniat untuk menghalang seseorang atau isterinya daripada perbuatan itu, mereka perlu diberitahu atau diberikan makluman. Seandainya perbuatan itu berlaku sebelum diberitahu, terlupa atau dipaksa, maka talak tidak berlaku.

Walau bagaimanapun, seandainya suami berniat melakukan talak dengan mengaitkan perbuatan seseorang atau isterinya semata-mata, maka talak akan berlaku, walaupun tanpa diberitahu, berlaku dengan terlupa atau dipaksa. ${ }^{35}$

\section{(ii) Pendapat kedua: Talak taklik dengan syarat adalah tidak sah}

Pendapat ini dipegang oleh mazhab al-Zohiri. ${ }^{36}$ Hujah mereka telah dijelaskan di atas, iaitu mereka menolak semua bentuk talak secara taklik atau bersyarat. Bagi mereka talak hanya boleh berlaku secara munjiz atau serta-merta seperti akad nikah.

\section{(iii) Pendapat ketiga: Talak taklik dengan syarat dilihat berdasarkan niat suami}

Pendapat ini dipegang oleh Ibn Taymiyyah ${ }^{37}$ dan anak murid beliau Ibn alQayyim. ${ }^{38}$ Seandainya suami melafazkan talak taklik dengan syarat berniat bersumpah, maka apabila perkara yang disyaratkan itu berlaku, talak tidak akan jatuh. Sebaliknya suami perlu membayar kafarah melanggar sumpah. Akan tetapi, seandainya suami melafazkan talak taklik dengan niat menceraikan isterinya jika apa-apa yang disyaratkan berlaku, maka ketika perkara yang disyaratkan itu berlaku, talak akan jatuh.

Mereka berhujah berdasarkan hadis riwayat Abu Hurairah bahawa Rasulullah SAW bersabda:

35 Al-Husain al-Baghawi. (1997). Al-Tahzīb, v6, 59-60. Daud al-Fathani. (1917). 'Ị̣ạh al-Bāblimazīd al-Nikāḥ bi al-Ṣawāb, 150.

36 Ibn Hazm. (t.t.). Al-Muhallā bi Al-Āthār, v9, 126.

37 Ibn Taymiyyah. (1987). Al-Fatāwā al-Kubrā. Dar al-Kutub al-'Ilmiyyah, v3, 235.

38 Ibn Qayyim. (1423H). I'lām al-Muwaqqi'̄̄n. Saudi Arabia: Dar Ibn al-Jawzi, v4, 441. 
"Barang siapa bersumpah atas sesuatu kemudian melihat yang lebih baik darinya, maka hendaklah ia mengambil yang lebih baik dan menebus sumpahnya". 39

Bagi mereka, apabila suami melafazkan talak taklik dengan berniat bersumpah, tindakan ini mengambil hukum sumpah. Berdasarkan hadis di atas, apabila terdapat perkara lain yang lebih baik daripada apa-apa yang disumpahkan, iaitu jatuh talak, maka pilihlah yanglebih baik, iaitu mengekalkan perkahwinan. Akan tetapi, suami dikehendaki membayar kifarat. ${ }^{40}$

Mereka turut berhujah dengan qias kepada fatwa para sahabat. Dalam fatwa tersebut memutuskan bahawa apabila seseorang itu bersumpah untuk memerdekakan hamba akan tetapi menarik balik sumpahnya, maka dia dikehendaki untuk membayar kifarat. Begitu juga dalam kes talak taklik dengan syarat apabila suami berniat bersumpah, talak tidak berlaku, sebaliknya suami dikehendaki membayar kifarat kerana melanggar sumpah. ${ }^{41}$

Pendapat rajih: Penulis berpandangan bahawa pendapat pertama, iaitu pendapat Jumhur Ulama yang mengatakan bahawa talak taklik dengan syarat akan berlaku dengan terjadinya perkara yang disyaratkan, adalah lebih rajih berdasarkan hujah yang diberikan oleh mereka.

Penulis berpendapat bahawa mengaitkan talak taklik dengan sumpah, seperti pendapat ketiga, adalah kurang wajar kerana ia tidak memenuhi syarat sumpah yang perlu disertai dengan menyebut nama Allah SWT atau sifatNya. $^{42}$

\section{(2) Talak Taklik dengan Masa}

Dinamakan juga dengan taklik al-mudaf. ${ }^{43}$ Al-mudaf bermaksud yang ditambah, iaitu ditambah pada lafaz talak taklik dengan masa tertentu. Seandainya sampai masa yang dinyatakan itu, maka jatuhlah talak. Hukumnya berbeza sama ada masa yang ditambah atau dikaitkan itu masa silam atau masa akan datang.

39 Muslim. (t.t.). Șahīh Muslim. Beirut: Dar Ihya' al-Turath al-'Arabi, v3, 1271 (No. 1650).

40 Ibn Qayyim. (1423H). I'lām al-Muwaqqi'īn, v4, 441-442.

41 Ibn Taymiyyah. (1987). Al-Fatāwā al-Kubrāa, v3, 235.

42 Sumpah tidak diterima tanpa menyebut nama atau sifat Allah SWT. Lihat, Mustafa Al-Khin et al. (1992). Al-Fiqh al-Manhajī, v3, 13, dan Muhammad al-Sharbini. (1994). Mughnī al-Muhtāj, v6, 181.

43 'Ala' al-Din al-Kasani. (1986). Badā'i' al-Șanā'i', v3, 134. 


\section{(a) Masa silam}

Apabila suami mengucapkan lafaz kepada isterinya: "Tertalak engkau bulan lepas", atau "Aku talak engkau bulan lepas". Ulama berbeza pendapat sama ada talak taklik dengan masa silam sah atau tidak kepada tiga pendapat:

\section{(i) Pendapat pertama: Talak tidak jatuh}

Pendapat ini dipegang oleh salah satu qawl mazhab Syafii, ${ }^{44}$ zahir katakata Imam Ahmad Ibn Hanbal ${ }^{45}$ dan merupakan pandangan Ibn Hazm alZohiri ${ }^{46}$ sama ada pada masa silam itu isterinya itu isterinya yang sah atau belum menjadi isterinya lagi. Mereka berpendapat sedemikian kerana apaapa yang dikatakan oleh suami itu adalah sia-sia memandangkan masa itu telah berlalu.

\section{(ii) Pendapat kedua: Talak jatuh serta-merta}

Pendapat ini dipegang oleh mazhab Maliki, ${ }^{47}$ zahir nas mazhab Syafii ${ }^{48}$ dan salah satu riwayat mazhab Hanbali ${ }^{49}$ sama ada pada masa silam itu isterinya itu isteri yang sah atau belum menjadi isterinya lagi. Perbuatan mengaitkan talak dengan masa silam adalah sesuatu perkara yang mustahil, maka adalah sia-sia. Akan tetapi talak tetap jatuh kerana suami telah melafazkannya.

(iii) Pendapat ketiga: Talak jatuh seandainya pada masa silam itu isteri merupakan isteri yang sah

Pendapat ini dipegang oleh mazhab Hanafi. ${ }^{50}$ Jika pada masa silam isteri itu bukan isterinya, maka suami menjatuhkan talak kepada perempuan yang bukan isterinya. Maka talak taklik itu tidak sah.

44 Muhammad al-Sharbini. (1994). Mughnī al-Muḥtāj, v4, 507.

45 Ibn Qudamah. (1968). Al-Mughnī, v7, 428. Ibn Qudamah. (1994). Al-Kāfī, v3, 141.

46 Ibn Hazm. (t.t.). Al-Muhallā bi al-Āthār, v9, 479.

47 Yusuf al-Qurtubi. (1980). Al-Kāfí. Saudi Arabia: Maktabah al-Riyad al-Hadithah, v2, 577. Ahmad al-Dardir. (t.t.). Al-Sharh al-Kabīr, v2, 390.

48 Muhammad al-Sharbini. (1994). Mughn̄̄ al-Muḥtāj, v4, 507. Al-Husain al-Baghawi. (1997). Al-Tahdhīb, v6, 48. Muhyi al-Din al-Nawawi. (t.t.). Al-Majmū'. Dar al-Fikr, v17, 210. Ibrahim al-Shayrazi. (t.t.). Al-Muhadhdhab, v3, 33.

49 Ibn Qudamah. (1994). Al-Kā fī, v3, 141.

50 Ali al-Marghinani. (t.t.). Al-Hidāyah, v1, 228. 
Penulis berpandangan bahawa pendapat kedua lebih rajih kerana suami telah berniat talak. Walaupun pada masa silam yang dikaitkan itu isterinya belum menjadi isterinya, talak tetap jatuh kerana ketika suami melafazkan talak taklik itu isterinya adalah isterinya yang sah.

\section{(b) Masa akan datang}

Apbila suami mengucapkan lafaz kepada isterinya: "Tertalak engkau esok", "Tertalak engkau minggu depan", atau "Tertalak engkau bulan depan". Ulama berbeza pendapat seperti yang berikut:

\section{(i) Pendapat pertama: Talak tidak jatuh}

Pendapat ini dipegang oleh mazhab al-Zohiri. ${ }^{51}$ Mereka berhujah dengan menyatakan bahawa kata-kata suami itu adalah sia-sia memandangkan terdapat kemungkinan salah seorang daripada mereka meninggal dunia dan menjadikan talak taklik tersebut tidak bermakna.

\section{(ii) Pendapat kedua: Talak jatuh serta-merta:}

Pendapat ini dipegang oleh mazhab Maliki. ${ }^{52}$ Mereka berhujah bahawa perkahwinan tidak boleh dihadkan dengan tempoh tertentu, seperti untuk tempoh seminggu atau sebulan. Begitu juga talak tidak boleh dihadkan untuk tempoh tertentu. Memandangkan talak telah dilafazkan, maka talak tetap berlaku dengan serta-merta.

\section{(iii) Pendapat ketiga: Talak jatuh apabila tiba masa yang dikaitkan:}

Pendapat ini dipegang oleh jumhur ulama daripada mazhab Hanafi, ${ }^{53}$ mazhab Syafii ${ }^{54}$ dan mazhab Hanbali ${ }^{55}$. Mereka berhujah dengan $\bar{a} t h \bar{a} r$ riwayat Ibnu Abbas r.a. yang mengatakan bahawa terdapat seorang lelaki telah berkata kepada isterinya: "Engkau tercerai pada hujung tahun ini", dan dia berkata: "dia menyetubuhi (isterinya) dalam tempoh masa itu

51 Ibn Hazm. (t.t.). Al-Muḥallā bi Al-Āthār, v9, 479.

52 Yusuf al-Qurtubi. (1980). Al-Kāfī, v2, 577. Ahmad al-Dardir. (t.t.). Al-Sharḥ al-Kabīr, v2, 390.

53 Ali al-Marghinani. (t.t.). Al-Hidāyah, v1, 228.

54 Muhammad al-Sharbini. (1994). Mughnī al-Muḥtāj, v4, 504.

55 Ibn Qudamah (1968). Al-Mughnī, v7, 423. 
hingga ke hujung tahun". Semasa dalam tempoh itu isterinya masih isteri yang sah, dan talak jatuh apabila habis hujung tahun.

Mereka turut berhujah dengan menggunakan qias terhadap perjanjian yang diberikan kepada seorang hamba yang akan terbebas jika memenuhi syarat tertentu seperti membayar sejumlah wang kepada tuannya. Begitu juga talak taklik, kerana kedua-duanya melibatkan pelepasan hak, iaitu pelepasan hak perhambaan oleh tuan terhadap hambanya, dan pelepasan hak perkahwinan oleh suami terhadap isterinya.

Penulis berpandangan bahawa pendapat ketiga yang mengatakan bahawa talak taklik dengan masa hadapan akan berlaku dengan sampainya tempoh yang dikaitkan adalah lebih rajih berdasarkan hujah-hujah yang diberikan. Tidak mungkin talak taklik dengan masa hadapan akan berlaku serta-merta, seperti pendapat mazhab Maliki, kerana itu bukanlah hal yang diingini atau dimaksudkan oleh suami. ${ }^{56}$ Perkara ini dikehendaki oleh suami pada masa depan, dan bukannya sekarang.

Seandainya mazhab Maliki mengqiaskan talak dengan akad nikah, bahawa akad nikah tidak boleh bersyarat, begitu juga talak tidak boleh bersyarat. Sepatutnya mereka berpandangan bahawa talak taklik dengan masa depan adalah tidak sah, kerana akad nikah yang bersyarat dengan tempoh adalah tidak sah.

Hujah mazhab Zohiri yang mengatakan talak taklik tidak sah berdasarkan hujah qias kepada akad nikah adalah kurang tepat, kerana talak taklik merupakan qiyasma'aal-fariq. Nikah merupakan akad, sedangkan talak taklik pula melepaskan hak atau meleraikan ikatan pernikahan.

\section{(3) Talak Taklik dengan Lafaz "Insya-Allah"}

Dinamakan dengan ta'liq bi masyiatillah,${ }^{57}$ iaitu mengaitkan berlakunya talak dengan keinginan atau kemahuan Allah SWT. Apabila suami melafazkan talak taklik dengan disertai lafaz "insya- Allah" seperti suami mengatakan kepada isterinya: "Aku ceraikan kamu insya-Allah (jika Allah kehendaki)", ulama berbeza pendapat kepada tiga:

56 Hujah ini digunakan oleh mazhab Al-Zohiriyyah. Lihat, Ibn Hazm. (t.t.). Al-Muhallā bi al-Āthār, v9, 479.

57 'Ala' al-Din al-Kasani. (1986). Badā'i'Al-Sanā'i', v3, 129. Ibn Rusd. (2004). Bidāyah al-Mujtahid. Al-Qahirah: Dar al-Hadith, v3, 99.; Muhyi al-Din al-Nawawi. (1991). Raw ḍah al-Tâalibìn, v8, 18. Mansur al-Bahuti. (t.t.), Kasysyāf al-Qinā', v5, 40. 


\section{(i) Pendapat pertama: Taklik talak dengan lafaz "insya- Allah"}

Lafaz talak taklik ini adalah tidak sah, maka talak tidak jatuh. Pendapat ini dipegang oleh mazhab Hanaf ${ }^{58}$ dan satu riwayat dalam mazhab Hanbali. ${ }^{59}$ Talak tidak sah kerana mengaitkannya dengan sesuatu yang tidak mungkin dapat diketahui, memandangkan tidak ada sesiapa yang tahu akan kehendak Allah SWT.

\section{(ii) Pendapat kedua: Talak taklik dengan lafaz "insya-Allah"}

Talak jatuh serta-merta. Pendapat ini dipegang oleh mazhab Maliki ${ }^{60}$ dan satu riwayat dalam mazhab Hanbali. ${ }^{61}$ Mereka berhujah dengan riwayat daripada Abu Hamzah yang mendengar Ibn Abbas berkata: "Apabila seorang lelaki berkata kepada isterinya: Aku talak engkau insya-Allah, maka isterinya tertalak (serta-merta)".

\section{(iii) Pendapat ketiga: Taklik talak dengan lafaz "insya-Allah"}

Bergantung pada niat suami. Seandainya suami melafazkannya dengan niat mengaitkan jatuh talak dengan kehendak Allah SWT, maka talak tidak berlaku kerana manusia tidak mampu untuk mengetahui kehendak Allah SWT sebelum perkara itu berlaku. Walau bagaimanapun, seandainya suami melafazkan "insya- Allah" dengan niat mengagungkan atau memuliakan Allah SWT, atau telah menjadi kebiasaan suami mengucap lafaz tersebut dalam kata-katanya, maka talak berlaku dengan sertamerta. Pendapat ini dipegang oleh mazhab Syafii. ${ }^{62}$

Penulis berpandangan bahawa pendapat ketiga yang meletakkan berlaku talak atau tidak pada niat suami adalah pendapat yang rajih. Hal ini bersesuaian dengan hadis Rasulullah SAW: "Sesungguhnya amalan itu tergantung kepada niat, dan setiap orang mendapat apa-apa yang diniatkan". ${ }^{63}$

58 'Ala' al-Din al-Kasani. (1986). Badā'i' Al-Sanā'i', v3, 28.

59 Ibn Qudamah. (1994). Al-Kāfì. Beirut: Dar al-Kutub al-'Ilmiyyah, v3, 137

60 Ibn Rushd. (2004). BidāyahAl-Mujtahid, v3, 99.Ahmad al-Dardir. (t.t.). Al-SharÍ alKabīr, v2, 392.

61 Ibn Qudamah. (1994). Al-Kāfî̀, v3, 137.

62 Muhammad al-Sharbini. (1994). MughnīAl-Muḥtāj, v4, 489. Daud al-Fathani. (1917). 'Ị̂āh al-Bāblimazīd al-Nikāh bi al-Sawāb, 137.

63 Al-Bukhari. (1422H). Șahīh al-Bukhārī. Dar al-Tuwaq al-Najah, v1, 6 (No. 1). 
Walau bagaimanapun, sekiranya suami mengaitkan talak taklik dengan kehendak seseorang, seperti suami berkata: "Tertalak engkau jika ayahmu mengehendakinya", atau kehendak isteri sendiri, seperti suami berkata: "Tertalak engkau jika engkau mahu". Seandainya ayah isteri mahupun isteri mengehendaki talak, maka jatuhlah talak. ${ }^{64}$

\section{(4) Talak Taklik dengan Perkara yang Mustahil}

Apabila suami melafazkan talak taklik dengan mengaitkan perkara yang mustahil, ulama berbeza pendapat seperti yang berikut:

\section{(i) Pendapat pertama: Talak Taklik dengan perkara mustahil tidak jatuh}

Perkara mustahil sama ada secara logik akal, seperti suami berkata: "Tertalak engkau jika kepala engkau masuk dalam lubang pin", atau secara adat: seperti suami berkata: "Tertalak engkau jika aku boleh terbang macam burung", atau dari segi syarak: "Tertalak engkau jika aku bunuh orang".

Pendapat ini dipegang oleh jumhur ulama daripada mazhab Hanafi, ${ }^{65}$ mazhab Maliki, ${ }^{66}$ mazhab Syafii ${ }^{67}$ dan satu riwayat dalam mazhab Hanbali. ${ }^{68}$ Mereka berhujah bahawa mengaitkan dengan sesuatu yang mustahil atau tidak wujud, bermakna selamanya syarat tersebut tidak akan terjadi. Oleh sebab itu, talak taklik dengan perkara mustahil adalah tidak sah. Begitu juga dengan talak taklik dengan perkara yang diharamkan oleh syarak, kerana orang Islam dilarang daripada melakukan perkara tersebut yang menjadikan syarat tersebut terbatal.

64 'Ala' al-Din al-Kasani. (1986). Badā'i' al-Ṣanā'i'. Ibrahim al-Shayrazi. (t.t.). AlMuhadhdhab, v3, 38. Ibn Qudamah. (1968). Al-Mughnī, v7, 342. Ibn Qudamah. (1994). Al-Kāfì, v3, 136, dan v3, 28.

65 'Ala' al-Din al-Kasani. (1986). Badā'i' Al-Șanā'i', v3, 132.

66 Ahmad al-Dardir. (t.t.). Al-Sharḥl-Kabīr, v2, 394.

67 Muhyi al-Din al-Nawawi. (t.t.). Al-Majmū', v17, 211.

68 Ibn Qudamah. (1968). Al-Mughnī, v7, 467. 


\section{(ii) Pendapat kedua: Talak taklik dengan perkara mustahil secara akal jatuh talak dengan serta-merta}

Perkara yang disyaratkan tidak wujud atau tidak mungkin berlaku, maka syarat taklik itu terbatal dan yang tinggal ialah lafaz talak, jadi talak jatuh dengan serta-merta. Pendapat ini dipegang oleh mazhab Hanbali ${ }^{69}$ dalam satu riwayat.

Penulis berpandangan bahawa lafaz talak taklik dengan perkara mustahil dari segi logik akal atau adat adalah tidak sah. Perkara yang mustahil dari segi akal atau adat pada kebiasaannya tidak akan berlaku. Oleh sebab itu, taklik tidak mungkin akan berlaku. Mungkin ada pendapat berpandangan bahawa perkara mustahil dari segi adat mungkin boleh berlaku seperti kejadian karamah yang terjadi kepada wali Allah yang mampu berjalan di atas air dan sebagainya. Walau bagaimanapun, karamah atau kejadian luar biasa tidak boleh dijadikan dasar pembinaan hukum syarak. Hukum syarak hanya boleh dibina atas dasar perkara yang lazim serta sering berlaku, dan tidak atas dasar perkara yang nadir atau jarang berlaku. Seperti kaedah yang menyebut bahawa:

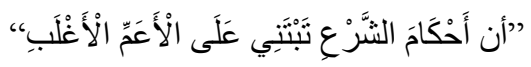

"Sesungguhnya hukum syarak dibina di atas perkara umum yang menjadi kebiasaan" $" 70$

$$
\text { "العبرة للغالب الثائع لا للنادر" }
$$

"Yang dikira pada perkara yang biasa berlaku, bukan pada perkara yang jarang berlaku" "71

Begitu juga lafaz talak taklik dengan perkara mustahil yang bercanggah dengan akidah adalah tidak sah. Seperti ucapan suami kepada isterinya: "Seandainya aku dapat lihat anak Allah, maka tertalaklah engkau". Hal ini tidak mungkin berlaku.

Walau bagaimanapun, talak taklik dengan perkara haram menurut syarak adalah sah, kerana tidak mustahil perkara tersebut boleh dilakukan oleh seseorang Muslim. Hal ini bersesuaian dengan pendapat al-Husain alBaghawi daripada kalangan ulama mazhab Syafii. ${ }^{72}$

69 Ibn.Qudamah. (1968). Al-Mughnī, v7, 467.

70 Usman ibn Ali. (1313H). TabyīnAl-Haqā 'iq. Al-Qahirah: Al-Matba'ah al-Kubra alAmiriyyah, v3, 45.

71 Ahmad ibn Muhammad Al-Zarqa'. (1989). Syarh Al-Qawā'id Al-Fiqhiyyah, 235. Salih ibn Ghanim. (1417H). Al-Qawā'id Al-Fiqhiyyah Al-Kubrā, 397.

72 Al-Husain al-Baghawi. (1997). Al-Tahdhīb, v6, 48. 
TALAK TAKLIK MENURUT UNDANG-UNDANG KELUARGA ISLAM DI MALAYSIA

\section{Pengertian Taklik Menurut Undang-Undang Keluarga Islam}

Dalam Syeksen 2. Tafsiran, Enakmen Undang-Undang Keluarga Islam (Negeri Selangor) 2003, ${ }^{73}$ ada memberikan definisi atau tafsiran kepada taklik, iaitu:

["ta'liq" ertinya lafaz perjanjian yang dibuat oleh suami selepas akad nikah mengikut Hukum Syarak dan peruntukan Enakmen ini].

Pada hemah penulis, tafsiran yang diberikan adalah tidak tepat kerana tafsiran yang berikan hanya menjurus kepada amalan pembacaan lafaz taklik rasmi selepas akad nikah. Perkara tersebut adalah tidak benar. Talak taklik boleh berlaku pada bila-bila masa sepanjang tempoh perkahwinan masih berkuat kuasa.

\section{Dua Kategori Taklik dalam Undang-Undang Keluarga Islam:}

Undang-undang Keluarga Islam mengiktiraf penceraian secara talak taklik. Dari segi amalan, terdapat dua jenis talak taklik yang diamalkan dalam masyarakat Islam di Malaysia.

\section{(1) Talak Taklik Biasa}

Talak taklik yang dilafazkan oleh suami dengan kehendak dirinya sendiri. Seperti ucapan suami kepada isterinya: "Kalau kau keluar rumah, tertalak engkau". Apabila isteri keluar rumah, maka tercerailah dia dengan sertamerta.

Tiada peruntukan khusus dalam Undang-Undang Keluarga Islam berkaitan dengan talak taklik biasa yang diucapkan oleh suami. Walau bagaimanapun, terdapat Arahan Amalan No. 8, Tahun 2006: Pengesahan Perceraian Lafaz Taklik selain Taklik Surat Perakuan Nikah dan Efek

73 Seksyen 2, Enakmen Undang-Undang Keluarga Islam (Negeri Selangor) 2003. 
Penalti di bawah Seksyen 124 Undang-Undang Keluarga Islam, ${ }^{74}$ yang mengatakan:

[Saya ingin menarik perhatian Y.A.A. kepada keputusan Mesyuarat Arahan Amalan Mahkamah Syariah Seluruh Malaysia Tahun 2006 pada 12 hingga 14 April, 2006 bersamaan 13 hingga 15 Rabiulawwal, $1427 \mathrm{H}$ di Shah Alam, Selangor yang telah bersetuju dan mengesahkan untuk menerima pakai arahan amalan bahawa prosiding kes pengesahan Perceraian Lafaz Taklik Selain Taklik Surat Perakuan Nikah tidak boleh dijadikan efek kepada tindakan penalti di bawah seksyen 124/125 Penalti Perceraian di luar Mahkamah dan tanpa kebenaran Mahkamah di bawah Akta/Enakmen/Ordinan Undang-Undang Keluarga Islam”.]

Maknanya, talak taklik biasa yang diucapkan oleh suami dianggap seperti talak biasa. Sekiranya berlaku di luar mahkamah tanpa keizinan pihak mahkamah, perlakuan ini tertakluk pada penalti seperti dalam seksyen 124: Penalti Perceraian di luar Mahkamah dan tanpa kebenaran Mahkamah, Akta Undang-Undang Keluarga Islam (Wilayah-Wilayah Persekutuan) 1984, yang menyebut:

[Seseorang lelaki menceraikan isterinya dengan melafazkan talak dengan apa-apa bentuk di luar Mahkamah dan tanpa kebenaran Mahkamah itu maka dia melakukan suatu kesalahan dan hendaklah dihukum denda tidak melebihi satu ribu ringgit atau dipenjarakan tidak melebihi enam bulan atau kedua-duanya. $]^{75}$

Peruntukan "melafazkan talak dengan apa-apa bentuk" termasuklah talak taklik. Pengesahan lafaz taklik rasmi tidak tertakluk pada penalti ini.

74 Arahan Amalan No. 2, Tahun 2010. Arahan Amalan ini telah membatalkan No. 8, Tahun 2006: Pengesahan Perceraian Lafaz Taklik Selain Taklik Surat Perakuan Nikah Dan Efek Penalti Di Bawah Seksyen 124 Undang-Undang Keluarga Islam, yang telah terkhilaf menjadikan pengesahan penceraian secara lafaz ta'līq yang dibaca oleh suami semasa akad nikah boleh dikenakan penalti.

75 Seksyen 124, Akta Undang-Undang Keluarga Islam (Wilayah-Wilayah Persekutuan) 1984. 


\section{(2) Taklik Rasmi}

Taklik yang dibaca oleh suami sebaik sahaja selesai upacara akad nikah dilangsungkan.

Kuasa mahkamah syariah mengesahkan pembubaran perkahwinan melalui pembacaan lafaz taklik termaktub dalam semua Undang-Undang Keluarga Islam di Malaysia. Dalam seksyen 50: Perceraian di bawah taklik atau janji, Undang-Undang Keluarga Islam (Wilayah-Wilayah Persekutuan) 1984, menyatakan bahawa:

[(1) Seseorang perempuan yang bersuami boleh, jika berhak mendapat perceraian menurut syarat-syarat surat perakuan ta'līq yang dibuat selepas berkahwin, memohon kepada Mahkamah untuk menetapkan bahawa perceraian yang demikian telah berlaku.

(2) Mahkamah hendaklah memeriksa permohonan itu dan membuat suatu siasatan mengenai sahnya perceraian itu dan, jika berpuas hati bahawa perceraian itu adalah sah mengikut Hukum Syarak, hendaklah mengesahkan dan merekodkan perceraian itu dan menghantar satu salinan rekod itu yang diperakui kepada Pendaftar yang berkenaan dan kepada Ketua Pendaftar untuk didaftarkan. $]^{76}$

Amalan membaca lafaz taklik selepas upacara akad nikah ini bukan sahaja berlaku di Malaysia, tetapi turut diamalkan di negara Nusantara lain seperti Singapura, Indonesia, Brunei Darussalam dan di Selatan Thai. ${ }^{77}$

\section{Lafaz taklik rasmi negeri-negeri di Malaysia}

Lafaz taklik telah menjadi prosedur rasmi kepada suami yang menjalankan akad nikah di setiap negeri di Malaysia, kecuali Perlis, perlu membaca

76 Seksyen 50, Akta Undang-Undang Keluarga Islam (Wilayah-Wilayah Persekutuan) 1984.

77 Syaefuddin Haris. (2013). Kedudukan Taklik Talak dalam Perkawinan Islam Ditinjau Dari Hukum Perjanjian. Arena Hukum,Vol. 6, No. 3, 336-359, Hisako Nakamura (2006), Conditional Divorce in Indonesia, (USA: President and Fellows of Harvard College), Mahyidin Hamat et. al. (2017). Talaq (Divorce) Procedure in the Provisions of Muslim Family and Inheritance Law of Patani Province, Southern Thailand. IOSR Journal of Humanities and Social Science (IOSR-JHSS), Vol. 22, Issue 2, Ver. I, 98-103, Nora Abdul Hak et. al. (2012). Right of Women to Obtain Divorce under Shari'ah and Islamic Family Law of Malaysia: With special reference to Ta'liq and Khulu'. Australian Journal of Basic and Applied Sciences, 6(11), 286-293. 
lafaz taklik tersebut yang disediakan oleh pihak Jabatan Agama Islam Negeri masing-masing. Di negeri Perlis pasangan diberikan pilihan untuk membaca lafaz taklik. Seandainya mereka bersetuju untuk membacakan lafaz taklik, maklumat ini akan direkodkan. ${ }^{78}$ Peruntukan penceraian secara lafaz taklik termaktub dalam seksyen 50: Perjanjian di bawah taklik atau janji, Enakmen Undang-Undang Keluarga Islam Negeri Perlis $2006 .{ }^{79}$

Tiada keseragaman lafaz taklik rasmi bagi negeri-negeri di Malaysia, kerana lafaz taklik tersebut disediakan oleh Majlis Agama Islam negeri masing-masing. Secara umum, terdapat dua lafaz taklik rasmi yang berbeza dari segi bentuk pembubaran perkahwinan yang diucapkan. Sebahagian lafaz taklik rasmi negeri-negeri berakhir dengan talak, dan sebahagian yang lain berakhir dengan khulu'.

Contoh yang berikut, ialah lafaz taklik rasmi yang berakhir dengan talak di negeri Terengganu:

"Saya dengan sesungguhnya melafazkan bahawa tiap-tiap kali saya tidak bersekedudukan dengan isteri saya (nama isteri) bagi selama tempoh empat bulan dengan tidak putus-putus, sama ada saya meninggal akan dia atau dia meninggal saya dengan ikhtiar atau dengan terpaksa dan tatkala ia mengadu ia kepada kadi dan tatkala sabit pada sisinya di atas ketiadaan sekedudukan selama itu maka tertalaklah isteri saya (nama isteri) itu dengan satu talak." $" 80$

Yang dapat difahami daripada lafaz taklik negeri Terengganu di atas yang menyebut "tiap-tiap kali saya tidak bersekedudukan" adalah bahawa setiap empat bulan suami tidak bersekedudukan dengan isterinya maka akan tertalaklah dia dengan talak satu. Begitulah seterusnya bagi empat bulan yang mendatang. Apabila suami meninggalkan isterinya selama dua belas bulan, maka tertalaklah dia dengan talak tiga ${ }^{81}$

Contoh lafaz taklik rasmi yang berakhir dengan talak di negeri Kelantan:

78 https://www.perlis.gov.my/jaips/index.php/ms/berita-jpbdp/301-tatacara-perkahwinanumat-islam-di-negeri-perlis, pada 4/4/2020.

79 Seksyen 50: Perjanjian di bawah ta'liq atau janji, Enakmen Undang-Undang Keluarga Islam Negeri Perlis 2006.

80 Sijil nikah negeri Terengganu.

81 Sila lihat, Ibrahim Al-Shayrazi. (t.t.), Al-Muhadhdhab, v3, 36. Al-HusainAl-Baghawi (1997). Al-Tahdhīb, v6, 58. 
"Bahawa adalah saya (nama suami) dengan ini bertaklik, iaitu manakala saya tinggalkan isteri saya (nama isteri) selama 4 bulan atau lebih dengan sengaja atau paksa atau saya atau wakil saya tiada memberi nafkah yang wajib kepadanya selama masa yang tersebut pada hal ia taat kepada saya. Atau saya menyakiti tubuh badannya atau saya tidak mengambil tahu mengenainya selama 4 bulan atau lebih atau (nama isteri) kemudian ia mengadu kepada mana-mana kadi/hakim Syarak jika disabitkan oleh kadi/hakim Syarak ini akan aduannya maka gugurlah talak saya dan dan tiap-tiap kali saya rujuk akan isteri saya tersebut tanpa redanya maka gugurlah pula satu talak." ${ }^{\prime 2}$

Yang membezakan antara lafaz taklik di negeri Kelantan dan negeri Terengganu ialah negeri Kelantan meletakkan syarat "tiada memberi nafkah yang wajib kepada isteri" dan "menyakiti tubuh badan isteri", sedangkan di Terengganu tidak. Di Terengganu mensyaratkan meninggalkan isteri "empat bulan dengan tidak putus-putus", tetapi tidak di Kelantan. Di Kelantan, isteri perlu mengadu atau membawa kesnya kepada pengetahuan hakim atau mahkamah untuk pengesahan, tetapi tidak di Terengganu. Di Kelantan, apabila telah sabit berlakunya talak, setiap kali suami merujuk isterinya dalam keadaan isterinya tidak reda, maka tertalaklah dia dengan satu talak. Syarat seperti ini tidak ada di Terengganu.

Contoh lafaz taklik rasmi berakhir dengan khulu' di negeri Selangor:

[Saya mengaku apabila saya tinggalkan isteri saya (nama isteri) selama empat bulan hijrah berturut-turut atau lebih dengan sengaja atau paksaan, dan saya atau wakil saya tiada memberi nafkah kepadanya selama tempoh yang tersebut pada hal ia taatkan saya atau saya melakukan sebarang mudarat kepada tubuh badannya, kemudian ia mengadu kepada mahkamah syariah, dan apabila sabit aduannya di sisi mahkamah syariah, dan ia memberi kepada Mahkamah Syariah, yang menerima bagi pihak saya sepuluh ringgit maka pada ketika itu tertalak ia dengan cara talak khuluk]. ${ }^{83}$

Lafaz yang hampir sama di negeri Kedah:

[Adalah saya (nama suami) dengan ini bertaklik, jika:

82 Sijil nikah negeri Kelantan, lafaz ta'liq yang hampir sama di negeri Melaka.

83 Sijil nikah negeri Selangor. 
(1) Saya tidak berma'syarah yang ma'ruf dengan isteri saya (nama Isteri) sama ada saya meninggalkan dia dengan sengaja atau paksaan atau dia meninggalkan saya dengan paksaan selama empat bulan qamariah berturut-turut atau lebih atau;

(2) saya atau wakil saya tidak memberikan nafkah kepadanya selama empat bulan berturut-turut atau lebih dan dia tidak disabitkan nusyuz oleh mana-mana mahkamah syariah atau:

(3) saya melakukan sebarang mudarat kepada tubuh badannya, penganiayaan atau lain-lain darar syarie terhadapnya, dan apabila dia mengadu kepada khadi atau hakim syarie dan sabit aduannya di sisi khadi atau hakim syarie dan ia memberi kepada khadi atau hakim syarie bagi pihak saya sebanyak sepuluh Ringgit Malaysia atau senilai dengannya maka pada ketika itu tertalaklah dia (nama Isteri) dengan satu talak khulu'i. $]^{84}$

Kedua-dua lafaz taklik negeri Selangor dan Kedah adalah sama, iaitu apabila mana-mana syarat taklik berlaku, isteri berhak mengadu kepada mahkamah. Seandainya mahkamah berpuas hati dengan kesahan aduan yang dibuat, maka isteri berhak melakukan khulu' atau tebus talak dengan membayar wang sebanyak sepuluh ringgit yang diterima oleh mahkamah bagi pihak suami. Yang berbeza ialah lafaz taklik di negeri Kedah meletakkan syarat "dia (isteri) meninggalkan saya (suami) dengan paksaan selama empat bulan qamariah berturut-turut atau lebih", iaitu isteri yang meninggalkan suami walaupun secara paksa, dan ini tidak terdapat di negeri Selangor. Begitu juga syarat "tidak berma 'syarah yang makruf dengan isteri" ada dalam lafaz taklik di negeri Kedah, tidak di negeri Selangor.

Di samping itu, perbezaan yang dapat dilihat dalam lafaz taklik di negeri Selangor menyebut syarat isteri berhak menuntut khulu' apabila suami meninggalkan isteri lebih empat bulan kamariah "dan" suami atau wakilnya tidak membayar nafkah kepada isteri. Sedangkan lafaz taklik di negeri Kedah menggunakan kata hubung "atau". Perbezaan yang kecil tetapi memberikan kesan yang sangat besar. Di Selangor, hanya sekiranya suami meninggalkan isteri dan pada yang sama tidak memberikan nafkah, isteri berhak menuntut khulu', sedangkan di Kedah salah satu daripada keadaan tersebut sudah memadai untuk isteri memohon khulu'.

Sijil nikah negeri Kedah. 
Dalam kes Mal Bil.: 04004-057-1245 Tahun 2010, Mahkamah Rendah Syariah Daerah Melaka Tengah, isteri telah menuntut pembubaran perkahwinan berdasarkan taklik rasmi yang telah dibaca oleh suami semasa mereka berkahwin. Isteri telah mengadu bahawa suaminya telah tidak menyediakan nafkah selama empat bulan berturut-turut. Setelah membuat kepastian wujud lafaz taklik rasmi yang dibaca oleh suami serta bukti kukuh suami telah gagal menyediakan nafkah kepada isteri melebihi empat bulan kamariah berturut-turut, pihak mahkamah memutuskan bahawa suami telah melanggar syarat taklik dan mengesahkan jatuh satu talak.

Penulis mencadangkan kajian lebih lanjut terhadap lafaz taklik di negeri-negeri di Malaysia serta kesan daripadanya, di samping membuat perbandingan antara lafaz-lafaz tersebut. ${ }^{85}$ Penulis turut menyarankan agar ada usaha untuk menyeragamkan kandungan lafaz taklik rasmi tersebut.

Tidak dapat dinafikan bahawa tujuan diperkenalkan pembacaan lafaz taklik selepas upacara akad nikah dijalankan adalah untuk menjaga kebajikan isteri daripada dizalimi atau dianiayai suami. ${ }^{86}$ Walau bagaimanapun, seperti pandangan Dato' Harun Din al-Hafiz, penulis berasa perlunya kajian semula yang lebih mendalam terhadap amalan atau prosedur membaca lafaz taklik sebaik sahaja akad nikah dijalankan seperti yang diamalkan hampir di seluruh negeri di Malaysia. Ada kemungkinan terdapat unsur paksaan kepada suami yang boleh menjejaskan kesahan lafaz taklik itu sendiri. ${ }^{87}$ Di samping itu, pelaksanaannya bercanggah dengan ruh atau maksud perkahwinan itu sendiri yang bermatlamatkan kekal hingga ke jannah.

85 Sebagai contoh kajian lafaz taklik talak di Melaka: Noormala Rabu et. al. (2017). "Ta'liq talak: Antara peruntukan perundangan dan amalan di Melaka". Dlm.: $2^{\text {nd }}$ International Islamic Heritage Conference (ISHEC 2017), 14-15 November 2017, Avillion Hotel Melaka.

86 Mahmud Saedon Awang Othman (2000). Hak Wanita dalam Undang-Undang Keluarga Islam. Dlm. Abdul Monir Yaacob (Ed.), Undang-UndangKeluarga Islam dan Wanita di Negara-Negara Asean. Kuala Lumpur: Institut Kefahaman Islam Malaysia (IKIM), 211; Mahmood Zuhdi Abdul Majid. (2000). Wanita dari Perspektif Undang-Undang Keluarga Islam di Malaysia. Dlm. Abdul Monir Yaacob (Ed.). Undang-UndangKeluarga Islam dan Wanita di Negara-Negara Asean. Kuala Lumpur: Institut Kefahaman Islam Malaysia (IKIM), 234.

87 Haron Din. (1977). Persoalan taklik talak: Suatu analisis tentang wajar tidaknya taklik talak terus diamalkan di Malaysia. Jurnal Islamiyat, No.1, 23-40. Lihat juga, Nor Fadzlina Nawi. (2003). Ta'liq agreement: A proposal for reformation. Wahana Akademik, 2(1), 85-98. 


\section{Syarat Sah Lafaz Taklik Menurut Undang-Undang Keluarga Islam di Malaysia}

Dalam Undang-Undang Keluarga Islam tidak menyatakan secara jelas syarat-syarat yang perlu dipenuhi bagi suami untuk melafazkan taklik. Walau bagaimanapun, Jabatan Kehakiman Syariah Malaysia (JKSM), melalui Arahan Amalan Perceraian Ta'līq (Arahan Amalan No. 8, Tahun 2007), ${ }^{88}$ meletakkan garis panduan, syarat serta kaedah pengesahan penceraian melalui lafaz taklik, seperti yang berikut:

[4. Syarat-Syarat Lafaz Ta'līq:

(1) Setiap lafaz ta'līq yang boleh didengar oleh Mahkamah hendaklah mengandungi unsur-unsur berikut :-

(a) perkara yang dita'līqkan ke atas isteri itu hendaklah perkara yang boleh berlaku;

(b) isteri yang dita'līqkan itu isterinya yang sah menurut Hukum Syara'; dan

(c) jika hal perkara yang disyaratkan berlaku dalam lafaz ta' līq perbuatan isteri atau orang lain, isteri atau orang lain itu hendaklah diberitahu sebelum hal perkara tersebut berlaku.

(d) Lafaz ta' līq tersebut hendaklah yang terdapat dalam:

(1) Surat Perakuan Ta'līq; atau

(2) Surat perakuan di hadapan Pendaftar Mahkamah atau Peguam Syarie dengan kehadiran isteri atau wakilnya.

(2) (i) Mana-mana lafaz ta'līq yang dikemukakan untuk sabitan cerai hendaklah menepati syarat-syarat Hukum Syara' yang mengandungi perkataan atau lafaz mana-mana yang berikut di bawah ini atau seumpamanya seperti dalam Jadual berikut -

(a) "apabila" atau

(b) “jika"atau

88 Amalan PerceraianTa'liq. ArahanAmalan No. 8, Tahun 2007. 
(c) "sekiranya" atau

(d) "kalau"atau

(e) “tiap-tiapkali”atau

(f) "manakala"

(g) dan lain-lain lafaz mengikut Hukum Syara'; dan

(ii) Sesuatu lafaz ta'līq itu tidak boleh diikuti atau diiringi dengan perkataan "Insyā Allah"]

Syarat lafaz taklik dalam arahan amalan ini terpakai kepada lafaz talak taklik biasa dan lafaz taklik rasmi. Perkara yang dapat difahami daripada syarat di atas ialah:

1. Syarat meletakkan bahawa taklik hanya sah jika dikaitkan dengan "perkara yang boleh berlaku". Syarat tersebut agak umum. Syarat tersebut tidak menjelaskan perkara yang diharamkan oleh syarak, seperti membunuh orang, sama ada perbuatan itu merupakan perkara yang boleh dilakukan atau tidak. Jumhur ulama tidak menerima taklik perkara yang diharamkan oleh syarak sebagai syarat taklik yang sah, sedangkan terdapat pandangan sebahagian ulama yang menerimanya sebagai syarat taklik yang sah. Begitu juga pada pandangan penulis yang menerimanya sebagai syarat taklik yang sah. Yang boleh difahami ialah lafaz talak taklik dengan mengaitkan perkara mustahil, sama ada mustahil dari segi akal mahupun adat adalah tidak sah. Perkara tersebut secara logik tidak boleh berlaku.

2. Syarat menetapkan bahawa "isteri yang ditaklik itu ialah isteri yang sah". Maknanya, suami yang mentaklikkan seorang perempuan yang bukan atau belum menjadi isterinya adalah tidak sah. Syarat perlu menjelaskan bahawa isteri yang masih berada dalam idah talak raj'i juga adalah sah mentaklikkannya, kerana sah mentalakkannya, bagi mengelakkan kesamaran.

3. Syarat meletakkan bahawa seandainya taklik itu berkaitan dengan perbuatan isteri atau orang lain, maka isteri serta orang yang dimaksudkan itu perlu diberitahu. Penulis berpandangan bahawa 
syarat itu benar seandainya suami berniat untuk menghalang isteri atau orang itu daripada melakukan sesuatu perbuatan. Walau bagaimanapun, seandainya suami berniat taklik dengan sematamata berlakunya perbuatan itu, dan bukannya berniat untuk menghalang perbuatan itu, maka talak berlaku walaupun tanpa pengetahuan isteri atau orang itu, terlupa atau dipaksa, seperti pandangan ulama yang dijelaskan sebelum ini.

4. Syarat menyebut bahawa kesan penceraian yang berlaku akibat taklik yang diucapkan bergantung pada kandungan lafaz taklik. Lafaz taklik rasmi yang dibaca adalah berbeza-beza mengikut negeri tempat akad nikah itu dijalankan. Sebahagian negeri lafaz taklik dikaitkan dengan talak, sedangkan sebahagian negeri yang lain dikaitkan dengan khulu'. Pembubaran perkahwinan secara khulu' dipilih kerana kedudukan talak ba'in, iaitu suami tidak memiliki hak untuk merujuk walaupun isteri masih dalam tempoh idah. Berbeza dengan talak yang kedudukannya talak raj' $i$, suami berhak merujuk selama isteri masih dalam tempohnya. Seandainya rujuk berlaku, maka seakan-akan tidak mencapai maksud tujuan pembacaan lafaz taklik rasmi itu diperkenalkan.

5. Syarat menetapkan bahawa lafaz talak taklik yang disertai dengan lafaz "insya-Allah" adalah tidak sah. Penulis berpandangan bahawa lafaz ini bergantung pada niat suami. Seandainya suami berniat bahawa ucapan "insya-Allah" untuk mengagungkan atau memuliakan Allah SWT, maka talak berlaku. Sebaliknya, seandainya suami berniat untuk menyerahkan jatuh atau tidak talak kepada kehendak Allah SWT, maka talak tidak berlaku.

6. Syarat menyatakan bahawa dalam lafaz talak itu perlu ada perkataan yang menunjukkan perkaitan, syarat atau perjanjian seperti: "apabila", "jika" dan "seandainya". Pada hemah penulis ini belum memadai. Yang lebih penting ialah uslub sighah atau jenis ucapan sama ada berbentuk insyai' atau khabari. Jenis ucapan inilah yang menentukan sama ada talak taklik berlaku atau tidak.

Dalam kes SS lwn MFA (Kes Rayuan No. 1000-054-0079-2016), di Mahkamah Rayuan Syariah Selangor, Perayu yang merupakan seorang isteri telah membuat rayuan terhadap keputusan Mahkamah Rendah 
Syariah Hulu Langat (Kes no. 10005-054-0327-2015) yang mengesahkan lafaz taklik yang dipohon sendiri oleh suaminya. Fakta kes mengatakan bahawa suami telah melafazkan taklik yang berbunyi: "Kalau ko keluar dari rumah ini, aku ceraikan ko dengan talak 3". Pada keesokan harinya suaminya bertanya kepada si isteri sama ada dia ada keluar rumah atau tidak. Isteri mengatakan: "Ya", walaupun pada hakikatnya tidak. Mendengar jawapan isteri, suami telah melafazkan kata-kata: "Fine, kita cerai talak 3”. Pihak Mahkamah Rendah Syariah Hulu Langat berpandangan bahawa lafaz kedua yang diucapkan oleh si suami tiada kaitan dengan lafaz taklik yang diucapkan sebelumnya dan memutuskan sabit jatuh talak tiga.

Dalam hujah perayu, iaitu si isteri, mengatakan bahawa lafaz taklik yang diucapkan oleh suami adalah sah. Walau bagaimanapun talak tidak berlaku, kerana dia tidak keluar rumah. Perayu menambah lagi bahawa lafaz talak yang diucapkan oleh suami pada keesokan harinya ada kaitan dengan lafaz taklik sebelumnya berdasarkan pertanyaan suami kepada si isteri sama ada dia ada keluar atau tidak semalam. Memandangkan talak taklik tidak berlaku disebabkan isteri tidak keluar rumah, maka lafaz talak yang diucapkan oleh si suami tidak memberikan kesan jatuh talak. Pihak Mahkamah Syariah Rayuan Selangor setelah meneliti hujah-hujah yang diutarakan menerima rayuan perayu. Mahkamah memutuskan bahawa Yang Arif Mahkamah Rendah Syariah Hulu Langat telah terkhilaf dan talak tidak berlaku.

Dalam kes yang lain, kes Permohonan no.: 11002-054-0024-2018, di Mahkamah Rendah Syariah Daerah Dungun, Terengganu, isteri telah membuat permohonan pengesahan cerai secara taklik biasa yang dilafazkan oleh suami berbunyi: "kalau awok balik ikut mok ayoh awok, jatuh satu talak". Fakta kes menyebut bahawa suami telah menjual barang kemas isteri tanpa izin. Bimbang isteri akan mengadu perkara tersebut kepada ibu bapanya yang bercadang untuk menziarahi rumah mereka di Johor, suami melafazkan taklik tersebut. Nenek kepada suami telah menghubungi ibu bapa isteri melarang mereka untuk mengunjungi rumah mereka bimbang perkara yang tidak diingini akan berlaku. Ibu bapa isteri membatalkan niat mereka untuk berziarah. Perkara ini berlaku pada bulan November 2017. Dalam bulan Januari 2018, ibu bapa isteri telah datang menziarahi rumah mereka tanpa memberitahu mereka terlebih dahulu. Memandangkan tiada apa-apa perkara berlaku dan isu suami menjual barang kemas itu tidak ditimbulkan, isteri telah mengikuti ibu bapanya balik ke Terengganu. 
Pihak Mahkamah Rendah Syariah memutuskan bahawa talak tidak berlaku ketika suami melafazkan talak taklik pada bulan November 2017 kerana isteri tidak pergi mengikuti ibu dan ayahnya balik ke kampung di Terengganu. Bagi pihak mahkamah, berdasarkan situasi yang berlaku, lafaz talak taklik yang dilafazkan oleh suami hanya bersifat sementara ketika situasi itu berlaku sahaja dan tidak bersifat umum. Oleh itu, pihak mahkamah memutuskan bahawa tindakan isteri mengikuti ibu bapanya balik ke kampung pada bulan Januari 2018 adalah tidak melanggar syarat taklik dan talak tidak jatuh.

Sekiranya dilihat daripada lafaz talak taklik yang diucapkan oleh suami dalam kes di atas, lafaz tersebut merupakan lafaz yang umum. Lafaz umum terpakai berdasarkan keumumannya kecuali terdapat perkara yang mengehadkannya. Jika dilihat dari sudut itu, perbuatan isteri mengikut ibu bapanya pulang ke kampung pada bulan Januari 2018 itu masih terikat dengan lafaz taklik yang diucapkan oleh suami. Hal ini bersesuaian dengan kaedah yang mengatakan bahawa:

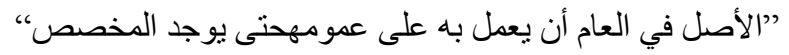

"Asal lafaz umum diambil berdasarkan keumuman maknanya sehingga terdapat perkara (atau dalil/bukti) yang mengkhususkannya". ${ }^{89}$

Walau bagaimanapun, pada hemah penulis, pihak mahkamah lebih cenderung untuk tidak mengambil pendekatan tersebut. Keputusan yang dibuat dianggap ada kewajaran dan kemaslahatannya, iaitu mengekalkan ikatan perkahwinan selama ada ruang yang membenarkan, selama perkara tersebut perkara ijtihadi. Hal ini berdasarkan kaedah:

$$
\text { "الأصل دوام النكاح" }
$$

"Prinsip asal ialah mengekalkan perkahwinan"

Merujuk kaedah yang menyebut "Asal lafaz umum diambil berdasarkan keumuman maknanya sehingga terdapat perkara (atau dalil/bukti) yang mengkhususkannya", keadaan dan tujuan suami mengucapkan lafaz taklik dalam kes di atas, iaitu menghalang isteri mengikut ibu bapanya pulang

89 Zakaria ibn Ghulam. (2002). Min Usūl al-Fiqh. Dar Al-Khiraz, 127.

90 Abdul Karim Al-Rafi'i. (1997). Al-'Azīzsyarḥ al-Wajīz. Beirut: Dar al-Kutub alIlmiyyah, v8, 168. 
bagi mengelakkan isteri mengadu masalah yang timbul boleh dijadikan dalil atau bukti bi al-hal (bukti berdasarkan keadaan) mengehadkan lafaz umum yang diucapkan oleh suami.

\section{KESIMPULAN}

Undang-Undang Keluarga Islam di Malaysia mengiktiraf penceraian secara taklik atau bersyarat dan apabila perlakuan tersebut dilakukan di luar mahkamah boleh dikenakan penalti denda tidak melebihi satu ribu ringgit atau dipenjarakan tidak melebihi enam bulan atau kedua-duanya. Amalan pembacaan lafaz taklik selepas upacara akad nikah yang menjadi prosedur rasmi di Malaysia yang pada hemah penulis perlu diteliti semula bagi mengelakkan unsur keterpaksaan yang mungkin boleh menjejaskan kesahan lafaz taklik. Syarat pengesahan penceraian secara taklik agak rumit berbanding dengan talak biasa kerana melibatkan tambahan perkara atau rukun termasuk sighah atau lafaz taklik serta perkara yang dikaitkan. Antaranya, lafaz talak taklik hendaklah dalam bentuk insyai dan bukan khabari. Terdapat beberapa cadangan penambahbaikan yang boleh dibuat dalam syarat lafaz taklik yang dinyatakan di dalam Arahan Amalan no. 8, 2007. Tafsiran makna taklik yang diberikan oleh Undang-Undang Keluarga perlu dinilai semula.

\section{RUJUKAN}

'Ala' al-Din al-Kasani. (1986). Badā'i' Al-Șanā'i'. Beirut: Dar Al-Kutub Al'Ilmiyyah.

Abu al-Hasan al-Maturidi. (1999). Al-ȘāwìAl-Kabìr. Beirut: Dar Al-Kutub Al'Ilmiyyah.

Abu Daud. (t.t.). Sunan $A b \bar{a} D \bar{a} w \bar{u} d$. Beirut: Al-Makrabah al-'Asriyyah. Ahmad Al-Dardir. (t.t.). Al-Sharh al-Kabīr. Dar Al-Fikr.

Ahmad ibn Muhammad al-Zarqa'. (1989). Sharh al-Qawā'id al-Fiqhiyyah. Beirut: Dar al-Qalam.

Akta Undang-Undang Keluarga Islam (Wilayah-Wilayah Persekutuan) 1984.

Al-Bukhari. (1422H). Șah̄̄h al-Bukhārī. Dar al-Tuwaq al-Najah.

Al-Hakim. (1990). Al-Mustadrak 'alā al-Ṣahihhaynī. Beirut: Dar al-Kutub al'Ilmiyyah.

Al-Husain al-Baghawi. (1997). Al-Tahzīb. Dar al-Kutub al-'Ilmiyyah. Al-Tirmizi. (1998). Sunan Al-Tirmizī. Beirut: Dar Al-Gharbi Al-Islami. Ali Al-Marghinani. (t.t.). Al-Hidāyah. Beirut: Dar Ihya' al-Turath al-'Arabi. 
Ali Mahmud Al-Zaqili. (2009). Al-Ṭalāq al-Mu'allaq: Mafhūmuhu wa Athāruhufì al-Fiqh al-Islāmī. Al-'Urdun: al-Majallah al-'Urdumiyyahfi alDirawat al-Islamiyyah, 5(1).

Arahan Amalan No. 2, Tahun 2010.

Arahan Amalan No. 8, Tahun 2006.

ArahanAmalan No. 8, Tahun 2007.

Daud al-Fathani. (1917). 'Ị̣̂ạḥAl-BāblimazīdAl-Nikāḥ bi Al-Ṣawāb. Yogyakarta: K-Media.

Enekmen Undang-Undang Keluarga Islam Negeri Perlis 2006.

Enakmen Undang-Undang Keluarga Islam (Negeri Selangor) 2003.

Haron Din. (1977). Persoalan taklik talak: Suatu analisis tentang wajar tidaknya taklik talak terus diamalkan di Malaysia. Jurnal Islamiyat, 1.

Hisako Nakamura. (2006). Conditional divorce in Indonesia. USA: President and Fellows of Harvard College.

https://www.perlis.gov.my/jaips/index.php/ms/berita-jpbdp/301-tatacaraperkahwinan-umat-islam-di-negeri-perlis, pada 4/4/2020.

Ibn Hazm. (t.t.). Al-Muḥallā bi al-Āthār. Beirut: Dar al-Fikr.

Ibn Nujaym. (t.t.). Al-Bahrr al-Rā’iq. Dar al-Kutub al-Islami.

Ibn Qayyim. (1423H). I'lām al-Muwaqqi'īn. Saudi Arabia: Dar Ibn al-Jawzi.

Ibn Qudamah. (1968). Al-Mughnī. Al-Qahirah: Maktab al-Qahirah.

Ibn Qudamah (1994), Al-Kāfî. Dar Al-Kutub al-'Ilmiyyah.

Ibn Rusd. (2004). Bidāyah al-Mujtahid. Al-Qahirah: Dar al-Hadith.

Ibn Taymiyyah. (1987). Al-Fatāwā al-Kubrā. Dar al-Kutub al-'Ilmiyyah.

Ibnu Majah. (t.t.). Sunan Ibn Mājah. Dar ihya’ al-Kutub al-Arabiyyah.

Ibrahim al-Shayrazi. (t.t.). Al-Muhadhdhab. Dar al-Kutub al-'Ilmiyyah.

Ibrahim Muhammad al-Hariri. (1999). Al-Qawā’id wa al-Dawābițal-Fiqhiyyah. Amman: Dar 'Ammar.

Jalal al-Din al-Suyuthi. (1983). Al-Asybah wa al-Nazā’ir. Beirut: Dar al-Kutub al-Ilmiyyah.

Kes Mal Bil.: 04004-057-1245 Tahun 2010, Mahkamah Rendah Syariah Daerah Melaka Tengah, Negeri Melaka.

Kes Permohonan no.: 11002-054-0024-2018, Mahkamah Rendah Syariah Daerah Dungun, Terengganu.

Mahmood Zuhdi Abdul Majid. (2000). Wanita dari perspektif Undang-Undang Keluarga Islam di Malaysia. Dlm. Abdul Monir Yaacob (Ed.), UndangUndang Keluarga Islam dan Wanita di Negara-Negara Asean. Kuala Lumpur: Institut Kefahaman Islam Malaysia (IKIM).

Mahmud Saedon Awang Othman. (2000). Hak wanita dalam Undang-Undang Keluarga Islam. Dlm. Abdul Monir Yaacob (Ed.), Undang-Undang keluarga Islam dan wanita di negara-negara Asean. Kuala Lumpur: Institut Kefahaman Islam Malaysia (IKIM). 
Mahyidin Hamat et al. (2017). Talaq (divorce) procedure in the provisions of Muslim family and inheritance law of Patani Province, Southern Thailand. IOSR Journal of Humanities and Social Science (IOSR-JHSS), 22(2), Ver. I. Mansur al-Bahuti. (t.t.). Kasysyhāf al-Qinā'. Dar al-Kutub al-'Ilmiyyah. Muhammad Al-Ramli (1984) NihāyahAl-Muḥhtāj, (Beirut: Dar Al-Fikr).

Muhammad Al-Sharbini (1994), MughnīAl-Muḥhtāj. Dar al-Kutub al-Ilmiyyah. Muhammad ibn Abu Bakr. (1986). MukhtārAl-Ṣị̣ăḥ. Beirut: Maktabah Lubnan. Muhammad ibn Ahmad al-Sarkhasi. (1993). Al-Mabsūtt. Beirut: Dar al-Makrifah. Muhammad ibn Idris al-Syafie. (1990). Al-Umm. Beirut: Dar al-Ma'rifah.

Muhammad ibn Ya'qub al-Fayruzabadi. (2008). Al-Qāmūs al-Muḥiṭ. AlQahirah: Dar al-Hadith.

Muhammad Mahmud. (2016). Ba'ḍuAdawāt al-Syarț wa Āthāruhāfī Aḥkām alTalāq. Dirasat: Ulum al-Shariah wa al-Qanun, 43(2).

Muhyi al-Din al-Nawawi. (1392H). Al-Minhāj Syarḥ Șah̄̄h Muslim. Beirut: Dar Ihya' al-Turath al-'Arabi.

Muhyi al-Din al-Nawawi. (1991). Raw d̦h al-Ṭālibīn. Beirut: al-Maktab alIslami.

MuhyiAl-Din al-Nawawi. (t.t.). Al-Majmu'. Dar Al-Fikr.

Muslim (t.t.). Șahīh Muslim. Beirut: Dar Ihya' al-Turath al-'Arabi.

Mutafa al-Khin et al. (1992). Al-Fiqh al-Manhajī. Damshiq: Dar al-Qalam.

Noormala Rabu, et. al. (2017). "Ta'liq talak: Antara peruntukan perundangan dan amalan di Melaka”. Dlm.: $2^{\text {nd }}$ International Islamic Heritage Conference (ISHEC 2017), 14-15 November 2017, Avillion Hotel Melaka.

Nor Fadzlina Nawi. (2003). Ta'liq Agreement: A Proposal for Reformation. Wahana Akademik 2(1).

Nora Abdul Hak et al. (2012). Right of women to obtain divorce under shari'ah and Islamic Family Law of Malaysia: With special reference to Ta'liq and Khulu', Australian Journal of Basic and Applied Sciences, 6(11).

Sa'di Abu Jayb. (2002). Al-Qāmūs al-Fiqhī. Damshiq: Dar al-Fikr.

Sajidah Taha Mahmud (2014). Al-Ṭalāq al-Mu'allaq: Māhiyyatuhu wa takyīfuhu al-Fiqhī wa al-Qānūnī. Majalah Kuliyyah al-Tarbiyyah Li al-Banat, 25(2).

Sijil nikah negeri Kedah.

Sijil nikah negeri Kelantan.

Sijil nikah negeri Melaka.

Sijil nikah negeri Selangor.

Sijil nikah negeri Terengganu.

SS lwn. MFA (Kes Rayuan No. 1000-054-0079-2016), Mahkamah Rayuan Syariah Selangor.

Syaefuddin Haris. (2013). Kedudukan Taklik talak dalam perkawinan Islam ditinjau dari hukum perjanjian. Arena Hukum, 6(3). 
Usmanibn Ali. (1313H). Tabyīn al-Haqā'iq. Al-Qahirah: Al-Matba'ah alKubra al-Amiriyyah.

WizarahAl-Awqaf. (1988). Al-Mawsū'ah al-Fiqhiyyah. Al-Kuwait: Wizarah alAwqaf wa al-Shu'un al-Islamiyyah.

Yusuf al-Qurtubi. (1980). Al-Kāfî. Saudi Arabia: Maktabah al-Riyad alHadithah.

Diperoleh (received): 26 Mei 2020

Diterima (accepted): 19 Disember 2020 